\section{Response to: 'Understanding bone fragility: theoretical explanation to non-physician health professionals' by Sugiyama}

We thank the author for his favourable and supportive comments ${ }^{1}$ on our article. ${ }^{2}$ We are pleased that our paper has highlighted the specific role that non-physician health professionals can play in the prevention and management of fragility fractures in people age 50 years or over and thank the author for adding theoretical explanations to support understanding of these roles.

We agree that the impact of some treatments to reduce skeletal fragility are lost after discontinuation and recognise the need for non-physician health professionals to encourage and support patients at high risk of fragility fracture in self-management and long-term behavioural change to optimise bone health, for example, adhering to antiosteoporosis medicines regimens.

Effective behavioural change interventions that support patients to engage with and continue moderate intensity physical activity (and also high intensity exercise as appropriate) for the long term, are important components of personalised treatment regimens and offer opportunities to prevent and manage fragility fractures in people 50 years or more.

\section{Jo Adams $\odot,{ }^{1}$ Nicky Wilson $\odot,{ }^{1}$ Tanja A Stamm $\odot^{2}$ \\ ${ }^{1}$ School of Health Sciences, University of Southampton, Southampton, UK ${ }^{2}$ Section for Outcomes Research, Medical University of Vienna, Wien, Austria}

Correspondence to Professor Tanja A Stamm, Section for Outcomes Research, Medical University of Vienna, Wien, 1090 Vienna, Austria; tanja.stamm@meduniwien.ac.at

Handling editor Josef S Smolen

Contributors JA, NW and TAS wrote the response to the letter.
Funding The authors have not declared a specific grant for this research from any funding agency in the public, commercial or not-for-profit sectors.

Competing interests None declared.

Patient and public involvement Patients and/or the public were not involved in the design, or conduct, or reporting, or dissemination plans of this research.

Patient consent for publication Not required.

Provenance and peer review Commissioned; internally peer reviewed.

(c) Author(s) (or their employer(s)) 2020. No commercial re-use. See rights and permissions. Published by BMJ.

$$
\text { Check for updates }
$$

To cite Adams J, Wilson N, Stamm TA. Ann Rheum Dis Epub ahead of print: [please include Day Month Year]. doi:10.1136/annrheumdis-2020-218049

Received 30 May 2020

Accepted 1 June 2020

\section{SLinked}

https://doi.org/10.1136/annrheumdis-2020-218003

Ann Rheum Dis 2020;0:1. doi:10.1136/annrheumdis-2020-218049

\section{ORCID iDs}

Jo Adams http://orcid.org/0000-0003-1765-7060

Nicky Wilson http://orcid.org/0000-0001-7404-7360

Tanja A Stamm http://orcid.org/0000-0003-3073-7284

\section{REFERENCES}

1 Sugiyama T. Understanding bone fragility: theoretical explanation to non-physician health professionals. Ann Rheum Dis 2020:10.1136/annrheumdis-2020-218003.

2 Adams J, Wilson N, Hurkmans E, et al. 2019 EULAR points to consider for nonphysician health professionals to prevent and manage fragility fractures in adults 50 years or older. Ann Rheum Dis 2020. doi:10.1136/annrheumdis-2020-216931. [Epub ahead of print: 24 Apr 2020]. 